\title{
Chinese or English Education? A Challenge Confronted by Chinese Government*
}

\author{
Geng Li-min \\ Henan University of Economics and Law, \\ Zhengzhou, China
}

\author{
Alexander Yuan \\ Utah Valley University, \\ Orem, USA
}

\begin{abstract}
The Chinese government decided to abolish the English examination from the Gaokao (College Entrance Examination in China) in 2013, which caused a hot discussion about English education in China. Some people thought that it should be abolished long ago because studying English stands in the way of Chinese study among students, and the country may lose its cultural identity; some believed that China cannot flourish without English education and the nation should emphasize the importance of English education rather than diminish it. The paper makes a qualitative study about the relationship between English and Chinese education through an interview, then discusses the underlying reasons why people call for abolishing English education in China, and finally predicts the future of English education in China.

Keywords: Gaokao (College Entrance Examination in China), English education, Chinese education, traditional Chinese culture
\end{abstract}

\section{Introduction}

On March 1st, 2013, the Ministry of Education of China issued the paper "The Opinion on the Deepening of the General Education Reform in 2013", which makes it clear that English will be dropped out from the traditional Gaokao (College Entrance Examination in China) in 2017, instead it will be put into the social test more than one time in one year (Ministry of Education of the People's Republic of China, 2013). In October 2013, the Beijing Municipal Education Commission has made the decision to reduce the weight of the English ability test from 150 to 100 points in the Gaokao. At the same time, the weight of the Chinese ability test will be increased from 150 to 180 points, which in the new scheme will go into effect in 2016. English learning for primary school students will also be postponed from 1st grade to 3rd grade. These reforms show their determination to cool down enthusiasm for English in education. Compared with Beijing, education authorities from other provinces have taken even more radical measures. For example, the Shandong government decided to cancel the English-listening test for the Gaokao in 2014, while the Jiangsu government is considering to exclude the English ability test from the Gaokao altogether (Hu, 2013).

It seems that the whole country is inviting this phenomenon. Many people thought that now it is time to hamper the enthusiasm towards English. They believed that "We are Chinese and we should pay more attention

\footnotetext{
"Acknowledgment: The support of the China Scholarship Council for the first author is greatly appreciated. Geng Li-min, M.A., assistant professor, Department of Foreign Languages, Henan University of Economics and Law. Alexander Yuan, Ph.D., assistant professor, Department of Foreign Languages, Utah Valley University.
} 
to Chinese instead of English, therefore, we should cultivate Chinese culture in our students instead of Western culture" (Wei, 2005; Yuan, 2004; Zhang, 2005; Pan, 2007). Nowadays, Chinese students spent a lot of time and energy learning English and Western culture and know more about Western culture than their own traditional culture, truly a pity and a shock to older Chinese generations.

The new policy changes have been backed by Chinese Communist Party think tanks, such as the Intelligence Research Academy, whose leader Zhang Shuhua argued in the Chinese People's Political Consultative Conference that students suffered a great deal in learning English and neglected the normal school study causing a crashing blow to the quality of education in China (Zhang, 2013). Chinese education is encountering an unprecedented crisis. The director of Chinese Press, Wang Xuming, published several micro-blogs to call the attention of the public to cancel the English courses, add traditional cultural education in elementary schools, and abolish children's English classes in society to liberate children and save Chinese (Modern Express, 2013). At the same time, these changes in the Gaokao also received considerable support from users on China's social Web - where there is a tendency to see English and Chinese at odds with one another. They believe that the Chinese culture deficiency among students results from too much English study. They blame the English study for the inefficient study of Chinese. For example, a comment left on a popular local media outlet, Phoenix's special feature reported about the policy change, a netizen from Guangxi wrote ( $\mathrm{Hu}, 2013)$ :

How many Chinese have been hurt by the English education? It should have been abolished long ago. For a period of time, some universities demanded that their students pass the English language examination as a precondition for their degree. Students are forced to spend all their time studying English and so neglect their own field.

Chinese is not only a language, it embodies our country's thousand-year culture. It covers both literature and humanity. Lifting the status of the Chinese language and cutting English from our education will benefit the country as well as the people.

Some netizens even expressed, "The English language is the nightmare of children, the tumor of Chinese people. It is time for surgery" ( $\mathrm{Hu}, 2013)$. On the other hand, some netizens are against the abolishment of English from the Gaokao arguing that English is an international language; how can China keep up with the development of the world without English language study. Wang Shouren, a professor from Nanjing university, and Chen Lin, a professor from Beijing Foreign Language University, both believed that:

Foreign language teaching and the foreign language level of a nation is a part of the national soft power. The purpose of the reform of foreign language in Gaokao should strengthen rather than weaken foreign language teaching. A country cannot develop healthily without the improvement of its foreign language level. (Lv, 2014)

English is very important for the development of a nation and its people. As Tsui and Tolldfson (2007) pointed out, "English is perceived by language policymakers in Asian countries as a multinational tool that is essential for achieving national goals and by individuals as an indispensable resource for personal advancement" (p. 18). But why are Chinese people calling for the abolition of English language education? What is the relationship between English and Chinese education? And what is the future of English education in China? It seems necessary to discuss these questions in this age of globalization.

This paper firstly made a qualitative study of people's attitudes toward the relationship between English and Chinese education through personal interviews. Then, it discussed briefly the possible reasons why people call for the abolition of English education in China. Finally, it concisely predicted the future of English education in China. 


\section{Literature Review}

Many researchers and reviewers in China have responded with articles about the degradation or abolishment of the English portion in the Gaokao after officials issued the reform of the English examination in the Gaokao. Some articles discuss the phenomenon from personal views without much investigation, such as Sun's (2014) "Degrading English in Gaokao Is Retrogression"; Sheng's (2014) "Degrading English in Gaokao Is a Kind of Culture Confidence"; and "Where English Will Go in the Tide of Education Reform in 2014" (English Network, 2014).

Some articles state that Chinese should decrease the "English fervor" in China. Hao (2014) discussed the advantages and disadvantages of "foreign languages fervor in China" and suggested that China should hamper the foreign language fervor by normalizing the foreign language education in China. Zhang (2014) discussed the problems faced by the reform of English education and analyzed the "Chinese cool" and "English hot". Chen (2014) analyzed the reasons why people are calling for the abolishment of English from the Gaokao, and explored what effects may fall on students because of the abolishment of English from the Gaokao.

Liu (2014) argued that the reform of English in the Gaokao is a trend of the times, which complies with public opinion.

Yang (2014) discussed the alterations of English education goals during the last 150 years in China. The education model of English education in China depends on the goal of the English education and the need of economic and social development.

Many foreign language experts in China believe that the purpose of the English reform is to direct English education to a more efficient and healthier system than before. In the forum of foreign language reform of the Gaokao (Lv, 2014), many famous researchers in the foreign language world made a hot discussion about the foreign language reform in the Gaokao. Many believe that the role of a foreign language is irreplaceable and that abolishing English in the Gaokao is not "educational equity" (Lv, 2014). Zhao (2014) believed that China should cultivate both Chinese and Western culture in English class to spread brilliant traditional Chinese culture. Learning English is for cross-cultural communication, not unilateral communication, so more emphasis should be placed on Chinese culture in English class.

From the literature review above, the conclusion can be made that many researchers discussed the English reform in the Gaokao from many aspects: the voice of the media, the reasons underlying the reform, associated advantages and disadvantages, the importance of English education, and what the reform leads to. However, no one has systematically discussed the relationship between Chinese and English education. Do the two contradict or complement each other? In order to solve the confusion faced by many Chinese today, conducting a study seems necessary to understand the relationship between Chinese and English education. When people understand the relationship, they know how to deal with each one wisely.

\section{Methodology}

\section{Participants}

The participants of the research were selected with great care and profound considerations regarding their gender, age, job, previous academic backgrounds, and other social and cultural concerns. All 90 participants were Chinese from Henan Province. Of the 90 participants, 30 were high school students, 30 were university teachers from different departments, and 30 were students' parents with different jobs. One 
third of the 30 parents were common workers, one third were government officials, and the other one third were self-employed with lower education level. The interviews were recorded and analyzed by the researchers later.

\section{Data Collection}

This research was conducted through interviewing 90 Chinese with different backgrounds. They were asked to describe their opinions and concerns about the relationship between Chinese education and English education with regard to the reform of the Gaokao. The conclusions and discussions were based on the interviewees' descriptions of their views and concerns; even though the paper was incapable of offering an ultimate explanation of the relationship between Chinese and English education, yet it offers a general view about the relationship between English and Chinese education to a great extent.

The purpose of the interview is to get an opinion about the relationship between Chinese education and English education from different social groups in China and help people make wise decision on how to deal with English and Chinese education in China.

The interview concentrates on the following seven questions, which were designed by the researchers with reference to the concerned questions people published on the Internet:

1. Do you think all the students should learn English at school?

2. Should English education be included in the compulsory education of China?

3. Do you think abolishing English from the Gaokao will degrade the enthusiasm of students' learning English?

4. Does English stand in the way of Chinese study?

5. Why do students have lost interest in traditional Chinese culture? Is it because of English study?

6. Do you think Chinese learning English will result in losing our culture identity?

7. Do you think this reform in the Gaokao is good or bad for English education in China?

\section{Data Analysis and Findings}

The analysis focused on the major interview questions. These questions were on issues, such as whether English education should be included in the compulsory education of China, whether the reform of the Gaokao will affect the enthusiasm of students' learning English, whether English study stands in the way of Chinese study, the reason why students lost interest in learning traditional Chinese culture, and whether Chinese learning English will result in losing our culture identity.

Most interviewees believed that English education should be included in the compulsory education of China and whether they want to learn it or not should be left to the students themselves. One official parent said, "Learning English could give children more opportunity in the job market. Maybe now they do not want to learn it, in the future they would find they benefit from learning English". One of the teachers said that grasping a foreign language is an essential quality of modern society; Chinese government should include English study in the compulsory education to meet the needs of Chinese people.

Most student participants thought that abolishing English from the Gaokao will degrade their enthusiasm in learning English. Students have been accustomed to the direction of the examination, and now, they feel uneasy about what they should do with English if it is abolished from the Gaokao. Several parents said that the main motivation of their children learning English is to earn a high grade in the Gaokao and enter a notable 
university. If it is abolished from the Gaokao, it will affect their learning enthusiasm and they may not want to study English any more. But most teacher participants expressed that only when English proficiency of a students is excluded from the evaluation of a student when entering a university can English be neglected.

Most interviewees considered that learning English did not stand in the way of their Chinese study. Some students even said, "Chinese study can help with English study. For example, if you can write well in Chinese, it is very possible that you will write well in English too". Yet, some parents thought learning English might take a lot of study time, consequently, affecting Chinese study. A notable observation is that most university teachers believed that English study stands in the way of students' chosen major. College students spend too much time learning English that they neglect their studies of major. The conclusion can be drawn that English study does take students' studying time, but not interfere with Chinese study. What is more, both languages can complement each other in some aspects.

Students gave complicated reasons why they lost interest in learning traditional Chinese culture. Among those surveyed, $80 \%$ of the students said that they have no interest in traditional Chinese culture because it is out of date and that Western culture is popular. Of parents surveyed, $85 \%$ believed that students lose interest in traditional Chinese culture because it is not emphasized in the school education. Of teachers surveyed, $74 \%$ considered that the overall culture context of China influenced people's opinion about traditional Chinese culture. One government official expressed that if students' traditional culture is to be improved, the nation must advocate and promote it in the society to influence the thought of the students, and blame should not be placed on English education for students' lack of traditional Chinese culture.

Only a few parents thought that learning too much English may result in losing cultural identity. Most parents, especially teacher participants, believed that one cannot lose his/her cultural identity just because of learning a foreign language. Instead, through learning English, he/she could express his/her culture to show his/her cultural identity in the world. One government official even said, "Nowadays, English is very important in presenting our national power in the world; we need to encourage our students to study English more to play an important role in the future".

\section{Discussion}

\section{The Relationship Between English and Chinese Education}

From the study, it is seen that Chinese education and English education are not at odds with each other. Decreasing the time of learning English does not necessarily mean that students will spend more time learning Chinese. On the contrary, abolishing English in the Gaokao may lead students to spending time engaged in other activities, such as sports or computer games. Furthermore, students may spend more time studying for the Chinese test primarily for higher grades in the examination, which may lead to more exam-oriented study rather than a quality-oriented study or improvement in their knowledge of traditional culture. Moreover, no one can deny the fact that English is the most popular international language in the world. No country can develop well without communication with the rest of the world. The achievement in China over the past 30 years is great evidence. In the 21 st century, China will develop more quickly than before, which cannot happen without communication with the world. English, as the international language, will be more valuable.

Admittedly, the popularity of English affects Chinese attitudes towards Chinese culture, but the blame does not lie solely on English learning. In fact, the weakening of traditional Chinese culture has its own complicated historical reasons. The Cultural Revolution in 1966 destroyed the traditions whether they were 
good or bad. Chinese people dare not learn anything related to the past; the opening to the outside world brought in the colorful Western culture, people had no choice but to accept the Western culture. What is more, in order to learn the advanced technology of the Western world, Chinese need to learn the language and culture to communicate successfully with Westerners. China put the economic development as the primary priority in order to improve the living standards of Chinese people during the past 30 years. China neglected its culture and placed importance on Western culture. Fortunately enough, the current Chinese government realized the importance of preserving the traditional Chinese culture, which is fortunate to Chinese and the world. In order to propagate traditional Chinese culture in the world, knowing English is necessary. Therefore, the task now is not to abolish English education in China, but rather to improve English education, emphasize Chinese culture in English classes, and direct English education to best serve the country.

Lin Qingxin, a professor from the English Department of Beijing University, said that "Languages are equal, no better or worse. But its development follows the rule of 'the survival of the fittest'. The popularity of English enriched Chinese. English language also accepts a lot foreign words from other languages in the world" (Zhu, 2005).

People's Daily Online (2006) reported that Global Language Monitor (GLM) stated that Chinglish is promoting great changes of English; a lot of Chinglish words entered the English language and became a major source of new English words.

Professor Lin Qingxin does not believe that the characteristics of a language can make it popular (Zhu, 2005). The society behind the language makes it popular-English stands for the powerful nations and culture. Even though China is the fastest developing country in the world and the language is receiving progressively more attention around the world, it is thus far incomparable with English. China needs to communicate with the world and propagate its brilliant culture with the help of English. Therefore, the importance of English is undeniable. All the reforms should intend to alter the inefficiency of English learning instead of degrading the importance of English.

\section{The Reasons for People Calling for the Abolition of English Education in China}

From history's perspective, the role and status of English have waxed and waned with the relationships of China with the outside world (Pride \& Liu, 1988). In order to improve its economy, host the Olympic games, and join the World Trade Organization (WTO), the government encouraged the whole nation to learn English. People believe that learning English can benefit their future; therefore, they spend a lot of energy and time learning English. That is utilitarianism in China: People learn English, because it is useful and can bring benefit to them.

Then, why do many people want to abolish English education now? The first reason may be that people feel disappointed about English education in China. Chinese people invest significant amounts of time, energy, and money to learn English. For those who have had studied English from elementary school to university, the time and energy they have spent on English learning is greater than that on Chinese language learning. Their result was not as expected; many students still cannot speak English and communicate with foreigners effectively. In fact, we should not minimize the achievement of English teaching and learning over the past. The English level of the entire nation has improved. Almost all the young people in China can read and write some English, and understand simple English. Even though their spoken English is poor, they can improve it quickly when there is a need. Even though there are some defects of English teaching in China, the 
achievements are impressive. The development of the economy in China received a substantial benefit from English education.

The second reason may be because many people think that learning English is useless. They think that there is no need for the whole nation to learn English and only those who need it should learn. In reality, millions of people have learned many years of English yet seldom use it after graduation. Less than $10 \%$ of people use English in their work (Chen, 2014). Therefore, it is unnecessary to require all the students to learn English in school and unnecessary to have English examinations in the Gaokao. However, even though some people seldom use English in their work, the fast development of the world makes English become a fundamental skill of modernized people. For example, if you do not know English, you may not know how to play computer games, how to operate a machine, or how to use an advanced camera; English has become the basic quality of an international citizen. If you want to be a world citizen, you need to know some English. What is more, many quantitative studies abroad showed that one's language ability, foreign language ability, or the fluency of language is closely related to their employment and income (Abrams, 1983; Tainer, 1988; Dustmann \& Soest, 2001; Leslie \& Lindley, 2001). Therefore, even from the utilitarian standpoint, all should learn English well. Furthermore, if we abolish English education from compulsory education, the opportunity of students learning English in the countryside will be deprived; in the countryside, students do not have other sources to learn English apart from school education. Therefore, abolishing English education at school during this age of world globalization is discouraged.

Another reason is that some people worry that English education consequently results in defective study of Chinese traditional culture. Many students know Western culture more familiarly than traditional Chinese culture, a pity to China. Therefore, to degrade the importance of learning English and upgrade the importance of Chinese is best. Chinese, as the native language of China, should be heavily emphasized. Nobody can deny this fact. Yet, upgrading Chinese study does not necessarily mean to degrade the English study. They are not at odds with each other; the cultures are complementary in many aspects. What is more, in order to spread the brilliant Chinese culture to the world, an understanding of English is necessary. Because English is the world language, no country can develop well without communication with other countries in the world. No country can develop without the world language English.

\section{The Future of English Education in China}

It seems that English teaching in China is not only a matter of foreign language teaching, it has a close relationship with the development of the whole country. To some extent, development and improvement in China depends on the quality of its English teaching (Du, 2001).

With the development of globalization, English will be used in increasingly more fields in Chinese citizens' lives. Abolishing English from the Gaokao does not mean the step of learning from the West becomes smaller; instead, China is taking a different route in order to learn English more scientifically. The removal of the English examination from the Gaokao is to pull students away from exam-oriented study habits and achieve quality education.

The development of China, or individuals, cannot be separated from English teaching. Therefore, Chinese officials should emphasize the importance of quality English education. In order to improve the students' traditional Chinese culture, China should ensure that traditional Chinese culture is learned in English classes. The government may add Chinese as a required course in the university to raise the traditional cultural sense in 
students. Only when China pays equal attention to Chinese and Western culture in its English education can it become successful in communicating with the world. Therefore, the future of English education is bright. English education will not be abolished; instead, it will become more efficient.

\section{Conclusion}

Although a lot of people opposed to the enthusiasm of people towards English education in China, yet the reality of China and world convinced us that China cannot develop healthily without English language study. No country can develop efficiently without the world language English in a global world. People in China resist the English education, because they are afraid that too much English study may lead to the weakness of Chinese study and even lead to the loss of cultural identity of some young people. This study showed that English education and Chinese education are not odds with each other, on the contrary, they can complement each other. English reform in Gaokao of Chinese government is to direct English education to a more efficient and healthier system than before rather than abolishing the English education in China. As we all know, the development of China benefited a lot from English education in the history. Though China is the fastest developing country in the world, it still needs English to communicate with the world. In order to propagate brilliant Chinese culture and let the world know more about China, learning English is necessary. All in all, the challenge faced by the Chinese government is how to develop the Chinese education and English education both healthily and efficiently rather than an either or question.

\section{References}

Abrams, B. A. (1983). An economic analysis of the language market. The Journal of Economic Education, 3, 40-47.

Beijing Municipal Education Commission. (2013). The new policy of Gaokao reform. Retrieved from http://gaokao.juren.com/ zhuanti/2014bjgkgg/ (In Chinese)

Chen, Q. L. (2014). Thinking over the calling on the abolishing English from Gaokao. Guangxi Education, 6, 6-8. (In Chinese)

$\mathrm{Du}, \mathrm{H}$. (2001). The globalisation of the English language: Reflections on the teaching of English in China. International Education Journal, 2(4), 126-133. Retrieved from http://www.flinders.edu.au/education/iej

Dustmann, C., \& Soest, A. V. (2001). Language fluency and earnings: Estimation with misclassified language indicators. The Review of Economica and Statistics, 4, 663-674.

English Network. (2014). Where English will go under the tide of education reform in 2014. English Journal for Middle School Students, 5, 8-10.

Hao, C. B. (2014). To cool the enthusiasm of learning English-Considering the controversy from the rational thinking of the policy of foreign language education. Language Education, 2, 8-13. (In Chinese)

Hu, J. (2013). China downplays English-language education with series of reforms. Retrieved from http:/globalvoicesonline. org/ 2013/12/07/china-to-downplay-english-language-in-education/

Leslie, D., \& Lindley, J. (2001). The impact of language ability on employment and earnings of Britain's ethnic communities. Economica, New Series, 272, 587-606.

Liu, H. F. (2014). Why is English the fist subject to be reformed in Gaokao? HuBei University Journal, 1, 96-99. (In Chinese)

Lv, J. J. (2014, August 7). The reform of English in Gaokao should be an opportunity. Social Science Newspaper, p. 4. (In Chinese)

Ministry of Education of the People's Republic of China. (2013). The opinion on the deepening of the general education reform in 2013. Retrieved from http://www.moe.gov.cn/publicfiles/business/htmlfiles/moe/s7315/201303/xxgk_148072.html (In Chinese)

Modern Express. (2013). The former spokesman of Ministry of Education issued an appeal on his micro-blog: Abolish primary English and help Chinese. Retrieved from http://www.js.xinhuanet.com/2013-09/10/c_117297038.htm (In Chinese)

Pan, W. G. (2007). Reflection on the "English fever" of the current society. Spoken and Writing Language, 4, 25.

People's Daily Online. (2006). Global Language Monitor: Many Chinglish into English. Retrieved from http://en.people.cn/200 602/06/eng20060206_240568.html 
Pride, J. B., \& Liu, R. S. (1988). Some aspects of the spread of English in China since 1949. International Journal of the Sociology of Language, 74, 41-70.

Sheng, X. (2014). Degrading English in Gaokao is a kind of culture confidence. Education and Vocation, $2,90$. doi: 10.13615/j.cnki.1004-3985.2014.04.042 (In Chinese)

Sun, S. L. (2014). Degrading English in Gaokao is retrogression. Education and Vocation, $2,90$. doi: 10.13615/j.cnki.1004-3985.2014.04.043 (In Chinese)

Tainer, E. (1988). English language proficiency and the determinatin of earnings among foreign-born men. The Journal of Human Resources, 1, 108-122.

Tsui, A. B. M., \& Tollefson, J. W. (2007). Language policy and the construction of national cultural identity. In A. B. M. Tsui, \& J. W. Tollefson (Eds.), Language policy, culture, and identity in Asian contexts (pp. 1-24). Mahwah: Lawrence Erlbaum Associates.

Wei, D. Y. (2005). Cool consideration about the "English fever" of teenager. China Youth Study, 10, 63-65. (In Chinese)

Yang, Y. Y. (2014). The change of the goals of English education in China in 150 years. Shanghai Jiaoyu Keyan, 4, 56-59. (In Chinese)

Yuan, J. W. (2004). Could English be degraded to optional course? China International News, 10, 1. (In Chinese)

Zhang, L. X. (2005). Cooling the national enthusiasm in learning English. China Reform, 10, 53-55. (In Chinese)

Zhang, S. H. (2013). "English fever" consume educational resources greatly, education stepped into a vicious cycle. Retrieved from http://news.china.com.cn/2013lianghui/2013-03/11/content_28208256.htm?bsh_bid=203335959 (In Chinese)

Zhang, T. W. (2014). The foreign language reform in Gaokao: Problem and thinking. Journal of PLA University of Foreign Languages, 5, 49-54. (In Chinese)

Zhao, C. H. (2014). How to propagate the brilliant Chinese traditional culture in the times when English is spread powerfully Shang Dong Social Sciences, 10, 177-181. (In Chinese)

Zhu, B. C. (2005). Utopia of English. Retrieved from http://culture.people.com.cn/GB/27296/3301820.html (In Chinese) 